\title{
Mycoplasma ovis comb. nov. (formerly Eperythrozoon ovis), an epierythrocytic agent of haemolytic anaemia in sheep and goats
}

\author{
Correspondence \\ Harold Neimark \\ neimah25@hscbklyn.edu
}

\author{
Harold Neimark, ${ }^{1}$ Brent Hoff ${ }^{2}$ and Martin Ganter ${ }^{3}$ \\ ${ }^{1}$ Department of Microbiology and Immunology, Box 44, College of Medicine, State University \\ of New York, 450 Clarkson Avenue, Brooklyn, NY 11203, USA \\ ${ }^{2}$ Animal Health Laboratory, Laboratory Service Division, University of Guelph, Guelph, Ontario,
Canada NIH 6R8 \\ ${ }^{3}$ Clinic for Pigs, Small Ruminants, Forensic Medicine and Ambulatory Service, School of \\ Veterinary Medicine, D-30173 Hannover, Germany
}

\begin{abstract}
Eperythrozoon ovis, an erythrocytic agent that causes haemolytic anaemia in sheep and goats, occurs worldwide and is currently thought to be a rickettsia. To determine the relationship between this agent and other haemotrophic bacterial parasites, the 16S rRNA gene of this organism was sequenced. Phylogenetic analysis revealed that this wall-less bacterium is not a rickettsia, but a mycoplasma. This mycoplasma is related closely to several other uncultivated, epierythrocytic mycoplasmas that comprise a recently identified group, the haemotrophic mycoplasmas (haemoplasmas). The haemoplasma group is composed of former Eperythrozoon and Haemobartonella species, as well as newly identified epierythrocytic mycoplasmas. Haemoplasmas parasitize the surface of erythrocytes of a wide variety of vertebrate animal hosts and are transmitted mainly by blood-feeding arthropod vectors. Recognition that $E$. ovis is a mycoplasma provides a new approach to dealing with this bacterium. It is proposed that $E$. ovis should be reclassified as Mycoplasma ovis comb. nov.
\end{abstract}

Eperythrozoon ovis is an uncultivated, wall-less bacterium that parasitizes the surface of sheep erythrocytes. This organism is transmitted by blood-feeding arthropods and parasitizes animals in sheep-rearing regions throughout the world. Signs of infection include mild to severe haemolytic anaemia, as well as icterus; animals may exhibit poor weight gain and depression, but death is rare in adults. Infections are frequently unapparent and chronic. E. ovis also infects goats, in which it results in more severe disease (Splitter et al., 1956; Kreier \& Ristic, 1963; Daddow, 1979; Mason et al., 1989; Mason \& Statham, 1991).

As E. ovis has not been cultivated, diagnosis is made by detection of organisms on erythrocytes in Romanowskytype or acridine orange-stained blood smears and by serological methods. Parasitism of erythrocytes often occurs at a low level and is transient; detection requires examination of repeated blood smears. However, erythrocyte parasitaemia can be as high as $100 \%$ in our experience; a high level of parasitaemia can occur even in subclinical infection and can persist for months (Overas, 1969;

Abbreviation: EM, electron microscopy.

The GenBank/EMBL/DDBJ accession number for the 16S rRNA gene sequence of the Hannover strain of Mycoplasma ovis is AF338268.
Brun-Hansen et al., 1997). E. ovis is completely resistant to penicillin and other antimicrobial agents that target the cell wall. Also, tetracycline treatment does not eliminate this agent from chronically infected animals.

This organism has been thought to be a rickettsia because of its obligate parasitism, erythrocyte localization, small size, staining properties and transmission by arthropod vectors. E. ovis and a number of similar haemotrophic bacteria have been classified in the order Rickettsiales, family Anaplasmataceae, in the genera Haemobartonella and Eperythrozoon (Kreier \& Ristic, 1984; Kreier et al., 1992). Recently, phylogenetic analysis of 16S rRNA gene sequences from four of these bacteria, Haemobartonella felis, Haemobartonella muris, Eperythrozoon suis and Eperythrozoon wenyonii, has demonstrated that these wallless bacteria are not rickettsiae, but that they are actually mycoplasmas (Neimark \& Kocan, 1997; Rikihisa et al., 1997; Neimark et al., 2001, 2002b). Here, the results of a phylogenetic study of $E$. ovis are reported.

\section{Electron microscopy (EM)}

Blood samples from E. ovis-infected sheep in Canada were used. For transmission EM, whole blood was fixed overnight in $2 \%$ glutaraldehyde $(\mathrm{v} / \mathrm{v})$ in $0 \cdot 1 \mathrm{M}$ HEPES buffer, 
$\mathrm{pH} 7 \cdot 0$, at $4{ }^{\circ} \mathrm{C}$. All solutions were used at a minimum of $10 \times$ blood volume. After fixation, samples were centrifuged gently to form a cell pellet, washed in HEPES buffer, postfixed in $1 \%$ osmium tetroxide $(\mathrm{w} / \mathrm{v})$ for $1 \mathrm{~h}$ at $4{ }^{\circ} \mathrm{C}$, washed again in buffer and dehydrated in a graded acetone series. Samples were embedded in Spurr's resin, polymerized at $60{ }^{\circ} \mathrm{C}$ overnight and ultrathin sections $(70-90 \mathrm{~nm})$ were cut. Sections were mounted on grids, stained with uranyl acetate and lead citrate and examined by using a Hitachi 7100 transmission electron microscope.

Samples for scanning EM were prepared by the following method. Fresh heparin-treated blood was placed on polylysine-coated slides that had been moistened with distilled water and allowed to stand for $30 \mathrm{~min}$ in a covered Petri dish. The material was then fixed in place on the slides by immersion in $2 \%$ glutaraldehyde (v/v) in $0 \cdot 1 \mathrm{M}$ HEPES buffer, $\mathrm{pH} 6 \cdot 8$, for $30 \mathrm{~min}$. This was followed by rinsing in HEPES buffer, post-fixing with $2 \%$ osmium tetroxide (w/v) in HEPES buffer for $30 \mathrm{~min}$, rinsing again with HEPES buffer and dehydration in a graded ethanol series. Slides were critical-point-dried from $100 \%$ ethanol by using liquid $\mathrm{CO}_{2}$ in a critical point drier, sputter-coated with 60 : 40 gold : palladium and examined with a Hitachi S- 4500 field emission scanning electron microscope.

The micro-organisms, as described previously by a number of investigators (e.g. Kreier \& Ristic, 1984; Zachary \& Basgall, 1985), are observed on the surface of erythrocytes in Giemsa-stained blood films as small bodies of approximately $0 \cdot 5-1 \cdot 0 \mu \mathrm{m}$ diameter. Morphology and epierythrocytic location of the organisms were also observed by using transmission and scanning EM (Figs 1 and 2). Transmission EM of thin sections confirmed that this coccoid organism is a prokaryote that lacks a cell wall and that these bacteria are located on the surface of the sheep erythrocyte membrane (Fig. 1). The organisms are $0 \cdot 3-0 \cdot 4 \mu \mathrm{m}$ in diameter and some have a $20-30 \mathrm{~nm}$ wide electron-dense layer that surrounds much of the cell. Both scanning and transmission EM showed the presence of several short fibrils that formed bridges between cells and the erythrocyte surface (Figs 1 and 2); the origin of these fibrils and whether they have a function in attachment is currently not known. These fibrils are similar to fibrils observed in thin sections of mycoplasma-infected erythrocytes from squirrel monkeys (Saimiri sciureus) (Aikawa \& Nussenzweig, 1972; Adams et al., 1984; Neimark et al., 2002a), pigs (Zachary \& Basgall, 1985), an opossum (Messick et al., 2002), putative Haemobartonella-infected or Eperythrozoon-like-infected erythrocytes from an owl monkey (Aotus trivirgatus) (Peters et al., 1974) and cynomolgus monkeys (Macaca fascicularis) (Dillberger et al., 1994).

\section{5 rRNA gene amplification, sequencing and phylogenetic analysis}

Blood samples to be used for sequencing the E. ovis $16 \mathrm{~S}$ rRNA gene were obtained from lambs that were born to a herd of 70 adult sheep in Germany. The lambs had failed to
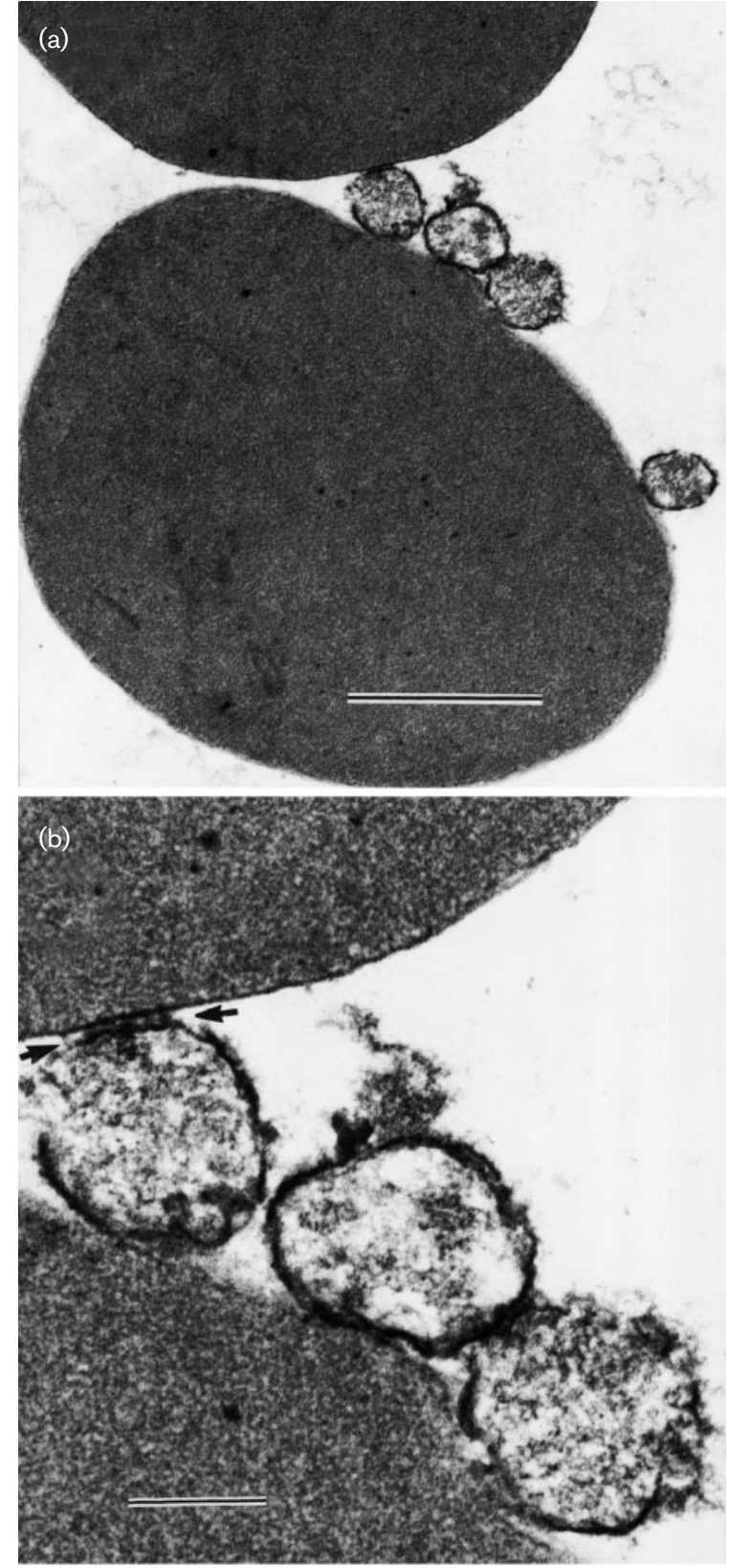

Fig. 1. Electron micrographs of a thin section of infected sheep erythrocytes. (a) Wall-less bacteria are located on the surface of erythrocytes. The surface of some organisms is partly surrounded by an electron-dense material. (b) Enlarged view. In some instances, fine fibrils can be seen to bridge between the bacterium and the erythrocyte surface (arrows). Bars, $0.1 \mu \mathrm{m}$ (a), $0.2 \mu \mathrm{m}$ (b).

gain weight and E. ovis was detected in blood smears by Giemsa and acridine orange staining. Initial blood samples showed that approximately $70 \%$ of erythrocytes were infected. Subsequently, $100 \mu$ l blood that showed 20-30\% infected erythrocytes was applied to FTA cards (treated filter paper for collecting and storage of blood or other biological samples for subsequent DNA analysis; Fitzco), 


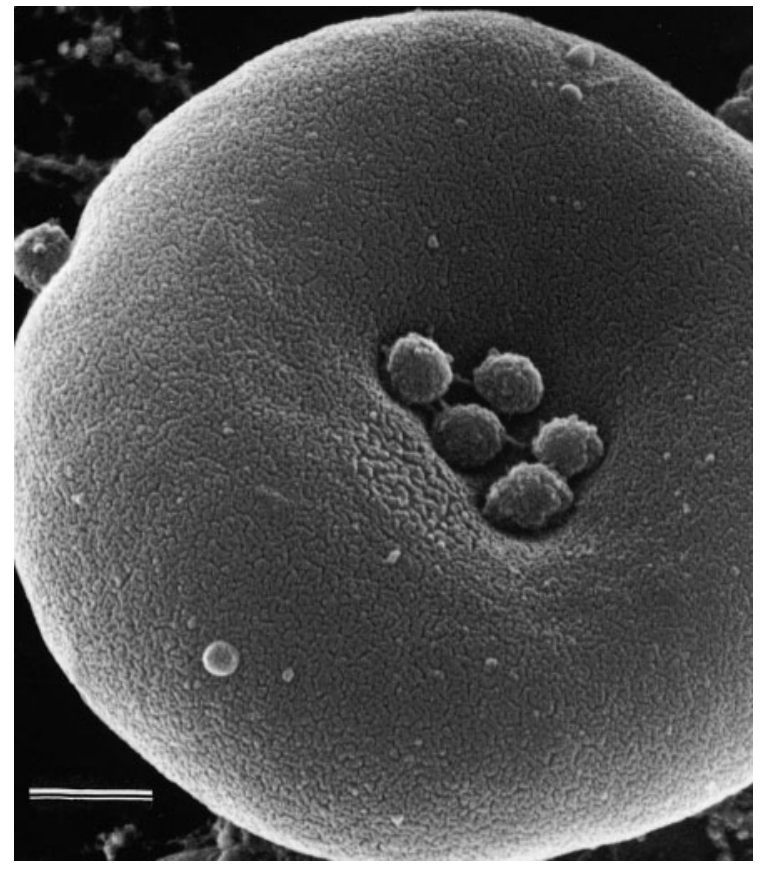

Fig. 2. Scanning electron micrograph showing infected sheep erythrocytes with several bacteria on the erythrocyte surface. Fine fibrils are visible between some of the bacteria and the erythrocyte surface. Bar, $0.5 \mu \mathrm{m}$.

air-dried and stored at ambient temperature until processed. Circles ( $3 \mathrm{~mm}$ in diameter) were punched from the filters and each circle was transferred to a PCR tube, washed three times for $10 \mathrm{~min}$ at room temperature with $500 \mu \mathrm{l} \mathrm{FTA}$ purification reagent (Fitzco) and then washed twice for 10 min with $500 \mu \mathrm{lE}(10 \mathrm{mM}$ Tris, $1 \mathrm{mM}$ disodium EDTA, $\mathrm{pH} 8 \cdot 0$ ) and air-dried.

Preserved blood from the sheep used for EM was not available for comparison with the samples from Germany, but stained blood smears on microscope slides were available, from which DNA was extracted by the following method. Slides were washed with 300-400 $\mu$ methanol by allowing a few drops to fall on the slide and pouring off until little colour was visible in the wash, and then airdried. The dry blood smear was scraped with an alcoholflamed, UV light-irradiated razor blade and the scrapings were transferred to a $1.5 \mathrm{ml}$ microfuge tube that contained $100 \mu \mathrm{l}$ TES extraction buffer $(100 \mathrm{mM}$ Tris, $10 \mathrm{mM}$ disodium EDTA, $100 \mathrm{mM} \mathrm{NaCl}, \mathrm{pH} 8)$ that contained $100 \mu \mathrm{g}$ proteinase $\mathrm{K} \mathrm{ml}^{-1}$ and $0.5 \%$ SDS (w/v). A filter pipette with the tip melted closed was used to aid transfer and a drop of extraction buffer was added if static electricity posed problems. The volume of extraction buffer was brought to 200-400 $\mu \mathrm{l}$ and an equal volume of buffer $\mathrm{AL}$ (QIAamp DNA blood mini kit; Qiagen) was added. The mixture was pulse-vortexed for $15 \mathrm{~s}$ and placed in heat block at $55^{\circ} \mathrm{C}$ for $1 \mathrm{~h}$ or longer until it was completely transparent (some sediment and blue colour will remain).
A volume of ethanol equal to the volume of extraction buffer was added and the mixture was pulse-vortexed; it was then centrifuged ( $6000 \mathrm{~g}$ for $1 \mathrm{~min}$ ) to pellet the sediment and the supernatant was transferred to a blood mini kit spin column in a $2 \mathrm{ml}$ collection tube (Qiagen). If more than one pipette transfer was required, the sample tube was centrifuged after each withdrawal to prevent transfer of sediment. The column was centrifuged $(6000 \mathrm{~g}$ for $1 \mathrm{~min}$ ) and transferred to a clean $2 \mathrm{ml}$ collection tube; the extraction continued with step 8 as described in the Qiagen protocol. DNA was eluted from the column with $50 \mu \mathrm{l}$ TE buffer ( $\mathrm{pH}$ 9).

Rigorous precautions were taken to avoid PCR contamination. 16S rRNA genes were amplified (31 cycles: $94{ }^{\circ} \mathrm{C}, 1 \mathrm{~min} ; 55^{\circ} \mathrm{C}, 1 \mathrm{~min} ; 72^{\circ} \mathrm{C}, 3 \mathrm{~min}$; with a $10 \mathrm{~min}$ extension for the last cycle) by using two conserved primers: $8 \mathrm{~F}$ ( $5^{\prime}$-AGAGTTTGATCMTGGCTCAG-3') and 1492R (5'-CGGTTACCTTGTTACGACTT-3'). PCRs $(50 \mu \mathrm{l})$ contained: $10 \mathrm{mM}$ Tris/ $\mathrm{HCl}, \mathrm{pH} 8 \cdot 3 ; 50 \mathrm{mM} \mathrm{KCl}$; $2.5 \mathrm{mM} \mathrm{MgCl} ; 200 \mu \mathrm{M}$ each of dATP, dCTP, dGTP and dTTP; $50 \mathrm{pM}$ each primer; and $2.5 \mathrm{U}$ Taq polymerase (Perkin Elmer). Positive and negative controls were included in all amplifications.

PCR products were purified with a spin column (Qiagen) and DNA was sequenced in both directions with a sequencing kit in an automated sequencer (Applied Biosystems). Sequencing primers were 8F, 339R, 360F, 519R, 482F, 797F, 907R, 1083R, 1088F and 1492R; primers 340F (5'-CCATATTCCTACGGGAAGCA-3') and 543R ( $5^{\prime}$-CCGGATAATGCTTGTGACCT- $\left.3^{\prime}\right)$ were also used for amplification and sequencing (see results for the nucleotide position numbering of these two primers).

Mycoplasma 16S rRNA gene sequences were obtained from GenBank. Alignments were made with the program CLUSTALW (Thompson et al., 1994) and adjusted manually. Phylogenetic analysis of the sequence alignment was carried out with the phylogenetic program package PHYLIP 3.51c (Felsenstein, 1993). The phylogenetic tree was constructed by using the neighbour-joining method, corrected for nucleotide substitutions by the Kimura two-parameter option with the transition/transversion ratio set at 2 . The dataset was resampled 1000 times and the resulting bootstrap percentage values are indicated at nodes of the tree (Fig. 3).

The 16S rRNA gene sequence of E. ovis determined in this study was from sheep blood from Hannover, Germany (the Hannover strain). Preserved blood from the E. ovisinfected sheep from Canada that were used in the EM study was not available for comparison, but stained blood smears from these sheep were available. As expected, analysis of DNA from blood smears showed that the Canadian E. ovis strain contained specific $16 \mathrm{~S}$ rRNA gene sequences that were shared only with the Hannover strain. Amplification of the region between nucleotide positions 340 and 543 (E. ovis numbering) was particularly helpful, 


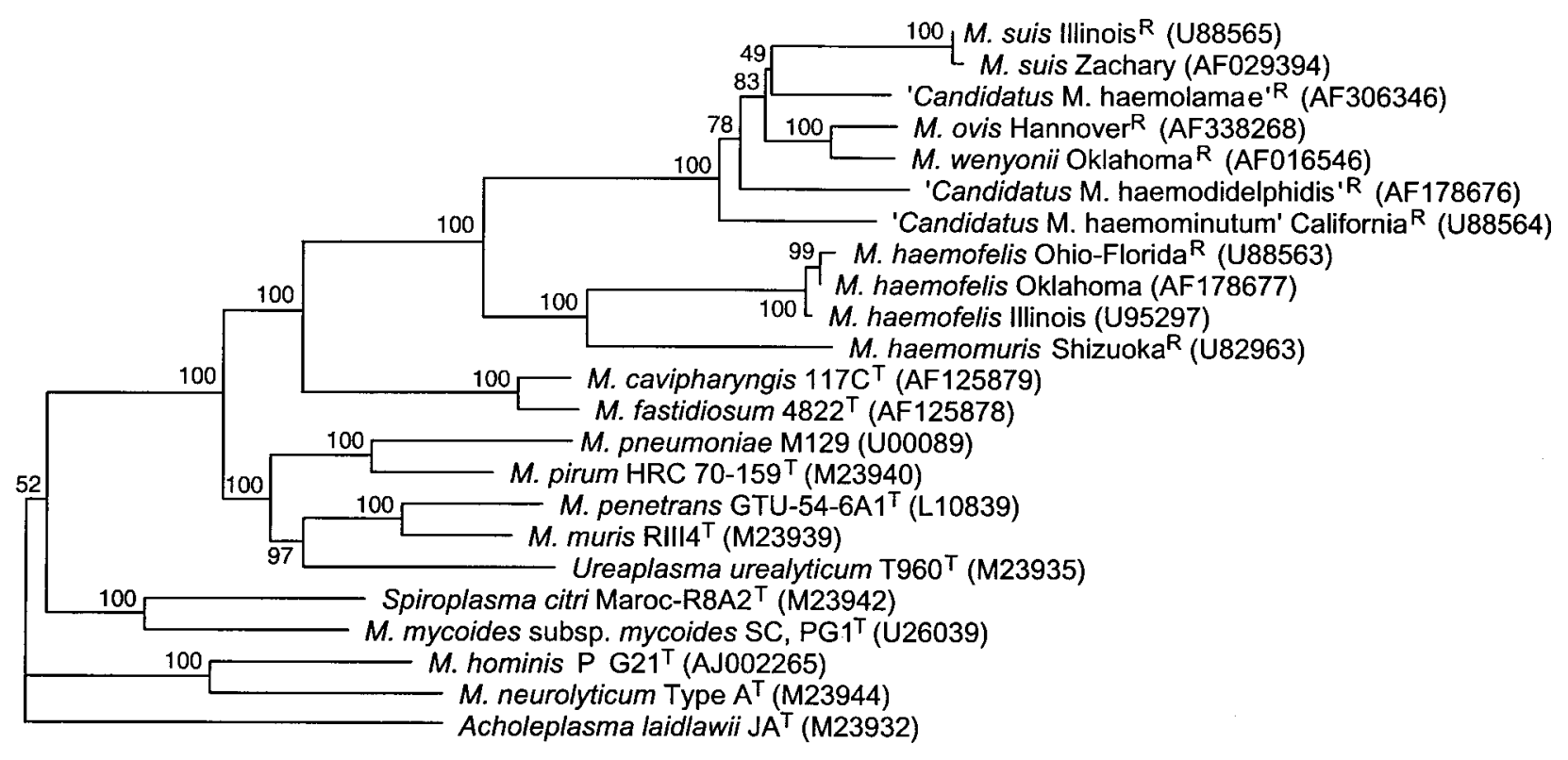

$0 \cdot 10$

Fig. 3. Phylogenetic tree based on 16S rRNA gene sequences, showing the relationship between $M$. ovis, other haemotrophic mycoplasmas and some members of the pneumoniae group, as well as species that represent other phylogenetic groups of mycoplasmas. Strain designations, where reported, and GenBank accession numbers are included. Organisms indicated with a superscript $\mathrm{R}$ are designated reference strains; these bacteria are not type strains as at present they are uncultivated, have not been cloned and cells or total genomic DNA have not been deposited in a public culture collection. Acholeplasma laidlawii was used as the outgroup. Bootstrap percentage values obtained from 1000 resamplings of the dataset are shown at the nodes. Bar, 1 substitution in $10 \mathrm{nt}$.

as this region is valuable for differentiating haemoplasma $16 \mathrm{~S}$ rRNA genes. However, it was not possible to obtain the entire gene sequence of the Canadian strain as, although controls were positive, amplifications of slide-extract DNA with some universal primers failed, possibly because the DNA on the slides was damaged. Consequently, comparison of the degree of similarity between the 16S rRNA genes of E. ovis strains from two geographically distant locations was not possible.

Comparison of the 16S rRNA gene sequence of E. ovis Hannover to sequences in GenBank by using BLASTN showed that nearly all matches were to mycoplasmas; highest similarity scores were obtained with haemotrophic mycoplasmas. Phylogenetic analysis produced an evolutionary tree that showed the relationship between E. ovis, other haemotrophic mycoplasmas, representative species of the pneumoniae group and representatives of other mycoplasma groups (Fig. 3). The tree shows that the E. ovis $16 \mathrm{~S}$ rRNA gene sequence clusters with those of other previously identified haemotrophic mycoplasmas (Neimark \& Kocan, 1997; Rikihisa et al., 1997) on a branch within the pneumoniae group of the genus Mycoplasma (Neimark \& Kocan, 1997; Johansson et al., 1999; Neimark et al., 2001). The phylogenetic tree shows that, among known haemotrophic mycoplasmas, E. ovis is related most closely to Mycoplasma wenyonii (95\% similarity). Reported cross-reactions between these two blood parasites with fluorescein-labelled sera from E. ovis- or M. wenyonii-infected animals (Kreier \& Ristic, 1963) might be a reflection of this relationship.

High bootstrap values at most of the branch-points in the phylogenetic tree (Fig. 3) indicate that this is probably a robust tree. However, the few low bootstrap values $(<50 \%)$ at some branch-points suggest that these branches may be due to chance.

Over the years, bodies observed on erythrocytes from nearly 30 different vertebrate hosts (ranging from fish to primates) and presumed to be Haemobartonella or Eperythrozoon species have been described and given species names on the sole basis of observing them in Giemsastained blood smears (Tyzzer, 1942; Weinman, 1944; Kreier et al., 1981). Although a few of these bodies may have been staining artefacts or misidentified erythrocytic structures, such as Pappenheimer bodies, Heinz bodies or HowellJolly bodies, it seems likely that the majority represent authentic haemotrophic bacteria that remain to be characterized. More recent observations of haemotrophic bacteria have been documented by experimental infection and EM studies, which have demonstrated wall-less bacteria on the 
surface of host erythrocytes (e.g. on raccoon erythrocytes; Frerichs \& Holbrook, 1971). Recently, haemotrophic organisms observed on erythrocytes from an opossum (Messick et al., 2002), llamas (Reagan et al., 1990; McLaughlin et al., 1991; Messick et al., 2002) and South American squirrel monkeys (Neimark et al., 2002b) have been identified as Mycoplasma species by molecular methods. It is proposed that classification of these haemotrophic bacteria should be changed, in order to reflect their actual phylogenetic position as mycoplasmas (Neimark et al., 2001, 2002b). These results support the suggestion that the remaining species of Haemobartonella ('Haemobartonella procyoni') and Eperythrozoon (Eperythrozoon parvum), both of which are wall-less and share identical properties with the haemotrophic mycoplasmas, will probably be found to be mycoplasmas (Neimark et al., 2001).

Mycoplasmas (class Mollicutes) comprise a large group of $>110$ species of wall-less bacteria that occur as pathogens or commensals in a wide variety of vertebrate animals, insects and plants. Mycoplasmas are notable for their low DNA G + C content (Neimark, 1970) and small chromosomes (Pyle et al., 1988; Neimark \& Lange, 1990). They have evolved through large losses of chromosomal DNA from low-G + C-containing, Gram-positive bacteria (Neimark, 1979; Woese, 1980) and are related most closely to streptococci (Neimark, 1979; Neimark \& London, 1982; Maniloff, 1996). All known animal mycoplasmas are parasites on mucous membranes of vertebrates; thus, the haemotrophic mycoplasmas display a novel mode of parasitism that has not been recognized previously in the mollicutes and have enlarged our understanding of the pathogenic capacity of mycoplasmas.

Identification of E. ovis as a mycoplasma provides a new perspective for clinicians and investigators in dealing with this organism, as it immediately allows information about mycoplasmas to be applied to this bacterium. Similarly, this identification augments our knowledge of this novel group of blood-parasitic mycoplasmas.

Whether the natural host range of E. ovis extends beyond sheep and goats is unclear. E. ovis has not been reported to infect cattle and is not infectious in calves, even when they are splenectomized (under the unnatural condition of splenectomy, the parasite was found for 9 days in the blood of a calf) (Hoyte, 1971). A splenectomized deer (Dama virginiana) infected with sheep blood that contained E. ovis was reported to yield positive blood films (Kreier \& Ristic, 1963). Also, an eland (Taurotragus oryx) inoculated with sheep blood that contained both Anaplasma ovis and E. ovis did not show any clinical symptoms, and neither organism was detected in daily blood smears after 50 days, but a sheep inoculated with day 51 blood from the eland eventually displayed both organisms in blood smears and developed fever, lethargy and loss of appetite (Enigk, 1942). In retrospect, the possibility that this sheep was infected from another source cannot be ruled out.
It is proposed that E. ovis should be transferred to the genus Mycoplasma as Mycoplasma ovis comb. nov., with the specific epithet 'ovis' retained for continuity. This namechange involves the transfer of a bacterial species that was previously recognized on the Approved Lists of Bacterial Species (Skerman et al., 1980); consequently, the Candidatus designation is not appropriate for this bacterium, as this designation is for novel, incompletely described taxa, to give them a provisional status (Neimark et al., 2001a).

\section{Description of Mycoplasma ovis comb. nov. (basonym Eperythrozoon ovis Neitz, Alexander and du Toit 1934)}

Mycoplasma ovis (o'vis. L. fem. n. ovis a sheep).

Epierythrocytic parasite of sheep and goats. Giemsa stain shows small, round bodies attached to the surface of erythrocytes. Erythrocytes can reach $100 \%$ infection. Organisms also are observed free in the blood during periods of fever in heavily parasitized animals. By using phase-contrast microscopy, M. ovis appears as a round cell. Cells seen in thin sections by EM are round or oval bodies of $0 \cdot 3-0 \cdot 4 \mu \mathrm{m}$ diameter and are applied closely to the erythrocyte membrane. A $20-30 \mathrm{~nm}$ wide electron-dense layer partially surrounds many of the organisms. M. ovis can produce mild to severe anaemia in normal sheep. Infections are frequently unapparent. Mortality from infection is rare, but anaemia and failure to gain weight occur in lambs. $M$. ovis is reported to share antigens with $M$. wenyonii (Kreier \& Ristic, 1963). Organisms in blood can be preserved by freezing untreated blood at $-18^{\circ} \mathrm{C}$ (M. Ganter, unpublished results) or in $10 \%$ DMSO $(\mathrm{v} / \mathrm{v})$ at $-70{ }^{\circ} \mathrm{C}$ (Brun-Hansen et al., 1997); $10 \%$ horse serum/ $10 \%$ glycerol, which is used for freezing other mycoplasmas at $-70^{\circ} \mathrm{C}$, should also be suitable. Transmission is by blood-feeding arthropods, including ticks [Haemaphysalis plumbeum and Rhipicephalus bursa (Nikol'skii \& Slipchenko, 1969)] and mosquitoes [Aedes camptorhynchus (Howard, 1975) and Culex annulirostris (Daddow, 1980)]. The stable fly (Stomoxis calcitrans) would appear to be a potential vector and subcutaneous injection of sheep with a suspension of fly material has resulted in infection, but transmission under natural conditions has not been demonstrated (Overas, 1969); similarly, injection of head lice (Linognathus ovillas) has also produced infection in sheep (Foogie \& Nisbet, 1964). An attempt to transmit the disease by removing sheep keds (the blood-sucking wingless fly Melophagus ovinus) from carrier sheep and injecting them intravenously into a splenectomized sheep (Neitz, 1937) or a normal susceptible sheep (Foogie \& Nisbet, 1964) did not produce visible infection. Infections can be transmitted by reusing needles during herd immunization and as a very small number of infected erythrocytes is sufficient to transmit disease (Mason \& Statham, 1991), it has been suggested that blood on tools during shearing or ear-tagging may contribute to spread in flocks (BrunHansen et al., 1997). Oral transmission has been shown 
experimentally (Overas, 1969). M. ovis occurs in sheeprearing regions throughout the world.

\section{Acknowledgements}

We thank Andrew Moore for help with EM.

\section{References}

Adams, M. R., Lewis, J. C. \& Bullock, B. C. (1984). Hemobartonellosis in squirrel monkeys (Saimiri sciureus) in a domestic breeding colony: case report and preliminary study. Lab Anim Sci 34, $82-85$.

Aikawa, M. \& Nussenzweig, R. (1972). Fine structure of Haemobartonella sp. in the squirrel monkey. J Parasitol 58, 628-630.

Brun-Hansen, H., Gronstol, H., Waldeland, H. \& Hoff, B. (1997). Eperythrozoon ovis infection in a commercial flock of sheep. Zentbl Veterinarmed B 44, 295-299.

Daddow, K. N. (1979). The transmission of a sheep strain of Eperythrozoon ovis to goats and the development of a carrier state in the goats. Aust Vet J 55, 605.

Daddow, K. N. (1980). Culex annulirostris as a vector of Eperythrozoon ovis infection in sheep. Vet Parasitol 7, 313-317.

Dillberger, J. E., Loudy, D. E., Adler, R. R. \& Gass, J. H. (1994). Hemobartonella-like parasites in cynomolgus monkeys (Macaca fascicularis). Vet Pathol 31, 301-307.

Enigk, K. (1942). Die empfanglichkeit der elenantilope für Anaplasma ovis und Eperythrozoon ovis. Dtsch Tropenmed $Z$ 46, 48-52 (in German).

Felsenstein, J. (1993). PHYLIP (phylogenetic inference package), version 3.51c. Department of Genetics, University of Washington, Seattle, WA, USA.

Foogie, A. \& Nisbet, D. I. (1964). Studies on eperythrozoon infection in sheep. J Comp Pathol 74, 45-61.

Frerichs, W. M. \& Holbrook, A. A. (1971). Haemobartonella procyoni sp. n. in the raccoon, Procyon lotor. J Parasitol 57, 1309-1310.

Howard, G. W. (1975). The experimental transmission of Eperythrozoon ovis by mosquitoes. Parasitology 71, xxxiii.

Hoyte, H. M. (1971). The infectivity of Theileria mutans, Eperythrozoon wenyoni and E. teganodes to sheep and of E. ovis to cattle. $\mathrm{Br}$ Vet J 127, lv-lvii.

Johansson, K.-E., Tully, J. G., Bolske, G. \& Pettersson, B. (1999). Mycoplasma cavipharyngis and Mycoplasma fastidiosum, the closest relatives to Eperythrozoon spp. and Haemobartonella spp. FEMS Microbiol Lett 174, 321-326.

Kreier, J. P. \& Ristic, M. (1963). Morphologic, antigenic, and pathogenic characteristics of Eperythrozoon ovis and Eperythrozoon wenyoni. Am J Vet Res 24, 488-500.

Kreier, J. P. \& Ristic, M. (1984). Genus III Haemobartonella; genus IV Eperythrozoon. In Bergey's Manual of Systematic Bacteriology, vol. 1, pp. 724-729. Edited by N. R. Krieg \& J. G. Holt. Baltimore: Williams $\&$ Wilkins.

Kreier, J. P., Dominguez, N., Krampitz, H. E., Gothe, R. \& Ristic, M. (1981). The haemotrophic bacteria: the families bartonellaceae and anaplasmataceae. In The Prokaryotes, pp. 2189-2209. Edited by M. P. Starr, H. Stolp, H. G. Trüper, A. Balows \& H. G. Schlegel. Berlin: Springer.

Kreier, J. P., Gothe, R., Ihler, G. M., Krampitz, H. E., Mernaugh, G. \& Palmer, G. H. (1992). The hemotrophic bacteria: the families Bartonellaceae and Anaplasmataceae. In The Prokaryotes, vol. 2, pp. 3994-4022. Edited by A. Balows, H. G. Trüper, M. Dworkin, W. Harder \& K.-H. Schleifer. New York: Springer.

Maniloff, J. (1996). The minimal cell genome: 'on being the right size'. Proc Natl Acad Sci U S A 93, 10004-10006.

Mason, R. W. \& Statham, P. (1991). Susceptibility of sheep and goats to Eperythrozoon ovis infection. Aust Vet J 68, 116-117.

Mason, R. W., Corbould, A. \& Statham, P. (1989). Experimental Eperythrozoon ovis infection in goats. Aust Vet J 66, 221-222.

McLaughlin, B. G., McLaughlin, P. S. \& Evans, C. N. (1991). An Eperythrozoon-like parasite of llamas: attempted transmission to swine, sheep, and cats. J Vet Diagn Invest 3, 352-353.

Messick, J. B., Walker, P. G., Raphael, W., Berent, L. \& Shi, X. (2002). 'Candidatus Mycoplasma haemodidelphidis' sp. nov., 'Candidatus Mycoplasma haemolamae' sp. nov. and Mycoplasma haemocanis comb. nov., haemotrophic parasites from a naturally infected opossum (Didelphis virginiana), alpaca (Lama pacos) and dog (Canis familiaris): phylogenetic and secondary structural relatedness of their $16 \mathrm{~S}$ rRNA genes to other mycoplasmas. Int J Syst Evol Microbiol 52, 693-698.

Neimark, H. C. (1970). Division of mycoplasmas into subgroups. J Gen Microbiol 63, 249-263.

Neimark, H. (1979). Phylogenetic relationships between mycoplasmas and other prokaryotes. In The Mycoplasmas, pp. 43-61. Edited by M. F. Barile \& S. Razin. New York: Academic Press.

Neimark, H. \& Kocan, K. M. (1997). The cell wall-less rickettsia Eperythrozoon wenyonii is a mycoplasma. FEMS Microbiol Lett 156, 287-291.

Neimark, H. C. \& Lange, C. S. (1990). Pulse-field electrophoresis indicates full-length mycoplasma chromosomes range widely in size. Nucleic Acids Res 18, 5443-5448.

Neimark, H. \& London, J. (1982). Origins of the mycoplasmas: sterolnonrequiring mycoplasmas evolved from streptococci. $J$ Bacteriol 150, 1259-1265.

Neimark, H., Johansson, K.-E., Rikihisa, Y. \& Tully, J. G. (2001). Proposal to transfer some members of the genera Haemobartonella and Eperythrozoon to the genus Mycoplasma with descriptions of 'Candidatus Mycoplasma haemofelis', 'Candidatus Mycoplasma haemomuris', 'Candidatus Mycoplasma haemosuis' and 'Candidatus Mycoplasma wenyonii'. Int J Syst Evol Microbiol 51, 891-899.

Neimark, H., Barnaud, A., Gounon, P., Michel, J.-C. \& Contamin, H. (2002a). The putative haemobartonella that influences Plasmodium falciparum parasitaemia in squirrel monkeys is a haemotrophic mycoplasma. Microbes Infect 4, 693-698.

Neimark, H., Johansson, K.-E., Rikihisa, Y. \& Tully, J. G. (2002b). Revision of haemotrophic Mycoplasma species names. Int J Syst Evol Microbiol 52, 683.

Neitz, W. O. (1937). Eperythrozoonosis in sheep. Onderstepoort J Vet Sci Anim Indust 9, 9.

Nikol'skii, S. N. \& Slipchenko, S. N. (1969). Experiments in the transmission of Eperythrozoon ovis by the ticks H. plumbeum and Rh. bursa. Veterinariia 5, 46 (in Russian).

Overas, J. (1969). Studies on Eperythrozoon ovis-infection in sheep. Acta Vet Scand Suppl 28, 1-148.

Peters, W., Molyneux, D. H. \& Howells, R. E. (1974). Eperythrozoon and Haemobartonella in monkeys. Ann Trop Med Parasitol 68, 47-50.

Pyle, L. E., Corcoran, L. N., Cocks, B. G., Bergemann, A. D., Whitley, J. C. \& Finch, L. R. (1988). Pulsed-field electrophoresis indicates larger-than-expected sizes for mycoplasma genomes. Nucleic Acids Res 16, 6015-6025.

Reagan, W. J., Garry, F., Thrall, M. A., Colgan, S., Hutchison, J. \& Weiser, M. G. (1990). The clinicopathologic, light, and scanning 
electron microscopic features of eperythrozoonosis in four naturally infected llamas. Vet Pathol 27, 426-431.

Rikihisa, Y., Kawahara, M., Wen, B., Kociba, G., Fuerst, P., Kawamori, F., Suto, C., Shibata, S. \& Futohashi, M. (1997). Western immunoblot analysis of Haemobartonella muris and comparison of $16 \mathrm{~S}$ rRNA gene sequences of H. muris, H. felis, and Eperythrozoon suis. J Clin Microbiol 35, 823-829.

Skerman, V. B. D., McGowan, V. \& Sneath, P. H. A. (1980). Approved lists of bacterial names. Int J Syst Bacteriol 30, 225-420.

Splitter, E. J., Anthony, H. D. \& Twiehaus, M. J. (1956). Anaplasma ovis in the United States: experimental studies with sheep and goats. Am J Vet Res 17, 487-491.

Thompson, J. D., Higgins, D. G. \& Gibson, T. J. (1994). CLUSTAL_W: improving the sensitivity of progressive multiple sequence alignment through sequence weighting, position-specific gap penalties and weight matrix choice. Nucleic Acids Res 22, 4673-4680.

Tyzzer, E. E. (1942). A comparative study of grahamellae, haemobartonellae, and eperythrozoa in small mammals. Proc Am Philos Soc 85, 359-398.

Weinman, D. (1944). Infectious anemias due to Bartonella and related red cell parasites. Trans Am Philos Soc 33, 243-338, 350.

Woese, C. R., Maniloff, J. \& Zablen, L. B. (1980). Phylogenetic analysis of the mycoplasmas. Proc Natl Acad Sci U S A7, 494-498.

Zachary, J. F. \& Basgall, E. J. (1985). Erythrocyte membrane alterations associated with the attachment and replication of Eperythrozoon suis: a light and electron microscopic study. Vet Pathol 22, 164-170. 